\title{
Sandstone degradation: an experimental study of accelerated weathering
}

\author{
Małgorzata Labus $\cdot$ Jerzy Bochen
}

Received: 7 October 2011/ Accepted: 14 March 2012/Published online: 1 April 2012

(C) The Author(s) 2012. This article is published with open access at Springerlink.com

\begin{abstract}
The investigated rock material belongs to the group of upper cretaceous quader sandstones which are very important construction stones in Poland and Germany. The mineral composition of the rocks is relatively uniform - they are quartzose sandstones. The most important feature is their good workability and comparatively high weathering resistance. Still, regardless of the apparent resemblance, the observations carried on buildings and monuments show differences in weathering processes. The undertaken test was an attempt to verify the proposed before rock classification, performed on the basis of parameterization of porosimetric cumulative intrusion volume curves. The aim of the experiment was the evaluation of the sandstone petrography (including the structure, texture and porosity of the rock) influence on the weathering process. The modelling of accelerated weathering was conducted in Chamber for Ageing Acceleration, where some weather circumstances were simulated (insolation, rain and frost). As the result of the weathering experiment it could be stated that the dominant mechanism of the sandstones deterioration was granular disintegration and weight loss as a consequence of sample destruction. The most important factor influencing rock deterioration is rock texture, especially the character of grain contacts. The effective porosity is a requisite of potential for the stone to take in and hold water, and hence of resistance to weathering. In case of silica-cemented sandstones, the deciding
\end{abstract}

\section{Labus $(\bowtie)$}

Institute of Applied Geology, Silesian University of Technology,

Akademicka 2, 44-100 Gliwice, Poland

e-mail: malgorzata.labus@polsl.pl

J. Bochen

Faculty of Civil Engineering, Silesian University of Technology,

Gliwice, Poland criterion influencing weathering resistance is pore structure. In case of sandstones with clay cement, the most important is mineral composition of the rock.

Keywords Accelerated weathering - Degradation · Pore area $\cdot$ Sandstone $\cdot$ Weathering resistance

\section{Introduction}

The strength of building stones and its changes caused by weathering conditions has been subject of interest for petrologists for many years of investigations. Research into sandstone weathering is concerned with morphological elements, processes operation, environmental conditions controlling the processes, and the materials upon which the processes operate over periods of time (Turkington and Paradise 2005). Empirical examinations of weathering forms are supplemented by experimental investigations, regarding physical processes, specifically salt and frost attack or chemical processes (Evans 1970; Goudie and Viles 1997; Ingham 2005; Sousa et al. 2005; Wells et al. 2006).

The Cretaceous sandstones belong to widely used natural building material, and hence they are deeply investigated (Ehling 1999; Götze and Siedel 2004, 2007). The investigated rock material belongs to the group of upper cretaceous quader sandstones which are very important as construction stones. They come from the currently operating quarry regions of Lower Silesia (Poland): the NorthSudetic Basin and the Intra-Sudetic Basin (Fig. 1), where they are found from the Cenomanium up to the Santonium strata. The mineral composition of the rocks is relatively uniform, as they represent mature quartzose arenites (Table 1). The most important feature is their good workability and comparatively high weathering resistance. Still, 


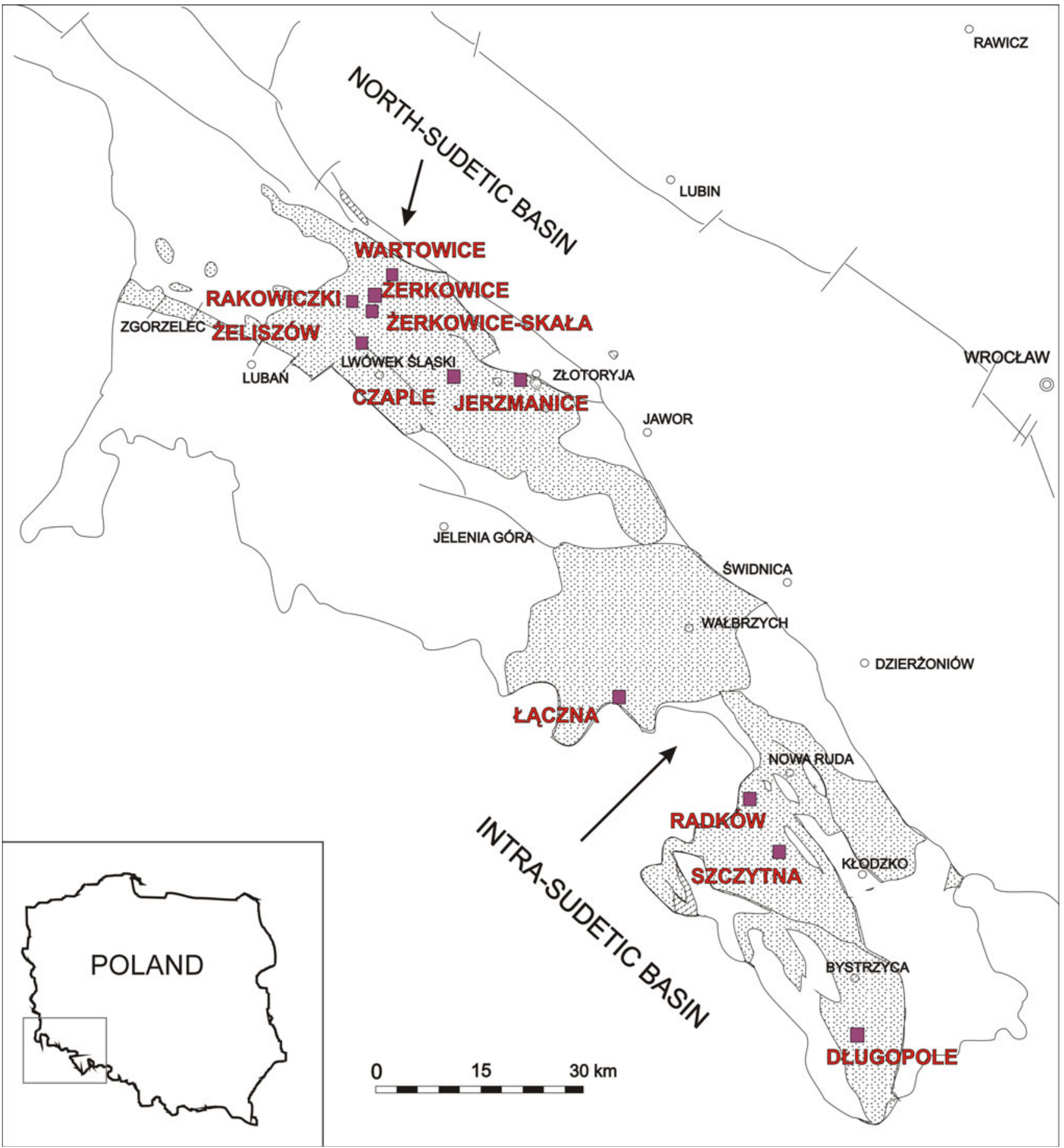

Fig. 1 Sampled deposits (marked with squares) situated in Lower Silesia (Poland)

regardless of the apparent resemblance, the observations carried on buildings and monuments, show differences in weathering processes.

The undertaken test was an attempt to verify the rock classification, proposed by the author before (Labus 2009, 2011) and presented here in brief. The classification was performed on the basis of parameterization of mercury intrusion porosimetry (MIP) cumulative curves. The aim of the experiment was the evaluation of the sandstone petrography (including structure, texture and porosity of the rock) influence on the weathering process. This study was focused on the weathering phenomena in moderate 
Table 1 Characteristic of the examined sandstones subjected to the modelling of accelerated weathering in CAA

\begin{tabular}{|c|c|c|c|c|c|c|c|c|}
\hline $\begin{array}{l}\text { Sedimentary } \\
\text { basin }\end{array}$ & $\begin{array}{l}\text { Stratigraphic } \\
\text { position }\end{array}$ & Quarry & Sample & $\begin{array}{l}\text { Sample } \\
\text { position }\end{array}$ & Grain size $(\mathrm{mm})$ & Colour & Cementing material & $\begin{array}{l}\text { Weathering } \\
\text { group }\end{array}$ \\
\hline \multirow[t]{18}{*}{$\begin{array}{l}\text { North- } \\
\text { Sudetic } \\
\text { basin }\end{array}$} & \multirow[t]{17}{*}{ Coniacian } & Żeliszów & $1 \mathrm{Ze}$ & $\begin{array}{l}\text { Upper part of } \\
\text { the quarry } \\
\text { wall }\end{array}$ & $\begin{array}{l}\text { Very fine-grained } \\
\quad(0.05-0.2)\end{array}$ & White & Siliceous-clay & I \\
\hline & & \multirow[t]{3}{*}{ Żerkowice } & $1 Z$ & E quarry bank & $\begin{array}{l}\text { Fine to coarse } \\
\text { grained }(0.1-1)\end{array}$ & $\begin{array}{l}\text { Yellowish- } \\
\text { grey }\end{array}$ & $\begin{array}{l}\text { Clay-chlorite, matrix } \\
\text { type }\end{array}$ & III \\
\hline & & & $2 Z$ & $\begin{array}{c}\text { Upper layer S } \\
\text { quarry bank }\end{array}$ & $\begin{array}{l}\text { Fine to coarse } \\
\text { grained }(0.1-0.8)\end{array}$ & $\begin{array}{l}\text { Yellowish- } \\
\text { white }\end{array}$ & $\begin{array}{l}\text { Clay-ferruginous- } \\
\text { chlorite, matrix } \\
\text { type }\end{array}$ & III \\
\hline & & & $3 Z$ & $\begin{array}{l}\text { Lower layer, } \\
\text { S bank }\end{array}$ & $\begin{array}{l}\text { Very fine to } \\
\text { medium grained } \\
(0.1-0.5)\end{array}$ & $\begin{array}{l}\text { Yellowish- } \\
\text { grey }\end{array}$ & $\begin{array}{l}\text { Siliceous-clay- } \\
\text { ferruginous }\end{array}$ & II \\
\hline & & \multirow[t]{3}{*}{$\begin{array}{l}\text { Żerkowice- } \\
\text { Skała }\end{array}$} & $1 \mathrm{~S}$ & $\begin{array}{l}\text { SE quarry } \\
\text { bank }\end{array}$ & $\begin{array}{l}\text { Fine to medium } \\
\text { grained }(0.1-0.4)\end{array}$ & $\begin{array}{l}\text { Grey with } \\
\text { yellow }\end{array}$ & Clay-ferruginous & I \\
\hline & & & $2 \mathrm{~S}$ & $\begin{array}{l}\text { SW quarry } \\
\text { bank }\end{array}$ & $\begin{array}{l}\text { Fine to medium } \\
\text { grained }(0.1-0.5)\end{array}$ & Yellow & $\begin{array}{l}\text { Clay-ferruginous- } \\
\text { siliceous }\end{array}$ & II \\
\hline & & & $4 S$ & $\begin{array}{l}\text { Central part of } \\
\text { quarry }\end{array}$ & $\begin{array}{l}\text { Fine to medium } \\
\text { grained }(0.1-0.5)\end{array}$ & $\begin{array}{l}\text { Grey with } \\
\text { yellow }\end{array}$ & $\begin{array}{l}\text { Clay-siliceous- } \\
\text { ferruginous }\end{array}$ & II \\
\hline & & \multirow[t]{3}{*}{ Rakowiczki } & $1 \mathrm{R}$ & S quarry bank & $\begin{array}{l}\text { Fine to medium } \\
\text { grained }(0.1-0.6)\end{array}$ & $\begin{array}{l}\text { Grey with } \\
\text { brownish }\end{array}$ & Clay-ferruginous & I \\
\hline & & & $3 R$ & $\begin{array}{l}\text { W quarry } \\
\text { bank }\end{array}$ & $\begin{array}{l}\text { Fine-grained } \\
(0.1-0.3)\end{array}$ & $\begin{array}{l}\text { Yellowish- } \\
\text { brown }\end{array}$ & Clay, matrix type & I \\
\hline & & & $5 \mathrm{R}$ & $\begin{array}{r}\text { Lower layer, } \\
\text { central part }\end{array}$ & $\begin{array}{l}\text { Fine to medium } \\
\text { grained }(0.1-0.4)\end{array}$ & $\begin{array}{l}\text { Whitish- } \\
\text { grey }\end{array}$ & $\begin{array}{l}\text { Clay-siliceous, } \\
\text { matrix type }\end{array}$ & III \\
\hline & & \multirow[t]{4}{*}{ Czaple } & $2 \mathrm{C}$ & $\begin{array}{l}\text { W part of } \\
\text { quarry, } \\
\text { lower layer }\end{array}$ & $\begin{array}{l}\text { Fine-grained } \\
\quad(0.1-0.3)\end{array}$ & Yellow & $\begin{array}{l}\text { Siliceous-clay- } \\
\text { ferruginous }\end{array}$ & III \\
\hline & & & $3 \mathrm{C}$ & $\begin{array}{l}\text { W part of } \\
\text { quarry, } \\
\text { upper layer }\end{array}$ & $\begin{array}{l}\text { Fine to medium } \\
\text { grained }(0.1-0.5)\end{array}$ & $\begin{array}{l}\text { Yellowish- } \\
\text { white }\end{array}$ & $\begin{array}{l}\text { Siliceous-clay- } \\
\text { ferruginous }\end{array}$ & III \\
\hline & & & $5 \mathrm{C}$ & $\begin{array}{l}\text { E part of } \\
\text { quarry, } \\
\text { upper layer }\end{array}$ & $\begin{array}{l}\text { Medium to coarse } \\
\text { grained }(0.1-1)\end{array}$ & $\begin{array}{l}\text { Yellowish- } \\
\text { grey }\end{array}$ & $\begin{array}{l}\text { Siliceous-clay- } \\
\text { ferruginous }\end{array}$ & III \\
\hline & & & $6 \mathrm{C}$ & $\begin{array}{l}\text { S part of } \\
\text { quarry, } \\
\text { upper layer }\end{array}$ & $\begin{array}{l}\text { Fine-grained } \\
(0.1-0.3)\end{array}$ & $\begin{array}{l}\text { Whitish- } \\
\text { grey }\end{array}$ & $\begin{array}{l}\text { Siliceous-clay- } \\
\text { ferruginous }\end{array}$ & I \\
\hline & & \multirow[t]{3}{*}{ Wartowice } & $1 \mathrm{~W}$ & $\begin{array}{l}\text { NE quarry } \\
\text { bank }\end{array}$ & $\begin{array}{l}\text { Fine to coarse } \\
\text { grained }(0.1-1.2)\end{array}$ & $\begin{array}{l}\text { Yellow } \\
\text { with } \\
\text { white }\end{array}$ & Clay-siliceous & III \\
\hline & & & $3 \mathrm{~W}$ & $\mathrm{~S}$ quarry bank & $\begin{array}{l}\text { Mostly coarse } \\
\text { grained }(0.2-1,4)\end{array}$ & Yellow & $\begin{array}{l}\text { Ferruginous- } \\
\text { siliceous-clay }\end{array}$ & I \\
\hline & & & $5 \mathrm{~W}$ & $\begin{array}{l}\text { Central part } \\
\text { lower layer }\end{array}$ & $\begin{array}{c}\text { Fine-grained } \\
(0.1-0.2)\end{array}$ & $\begin{array}{l}\text { Yellowish- } \\
\text { grey }\end{array}$ & $\begin{array}{l}\text { Clay-siliceous- } \\
\text { ferruginous }\end{array}$ & II \\
\hline & Turonian & Jerzmanice & $1 \mathrm{~J}$ & $\begin{array}{l}\text { Lower layer } \\
\text { of the } \\
\text { outcrop }\end{array}$ & $\begin{array}{l}\text { Fine to coarse } \\
\text { grained }(0.1-3)\end{array}$ & Grey & $\begin{array}{l}\text { Clay-siliceous- } \\
\text { ferruginous }\end{array}$ & III \\
\hline \multirow[t]{4}{*}{$\begin{array}{l}\text { Intra-Sudetic } \\
\text { basin }\end{array}$} & \multirow[t]{2}{*}{$\begin{array}{l}\text { Upper } \\
\text { Turonian }\end{array}$} & \multirow[t]{2}{*}{ Szczytna } & $3 \mathrm{Sz}$ & $\begin{array}{l}\text { Central part, } \\
\text { lower layer }\end{array}$ & $\begin{array}{l}\text { Fine to medium } \\
\text { grained }(0.1-1)\end{array}$ & $\begin{array}{l}\text { Whitish- } \\
\text { grey }\end{array}$ & Siliceous-clay & II \\
\hline & & & $4 \mathrm{Sz}$ & $\begin{array}{l}\text { E quarry } \\
\text { bank, upper } \\
\text { layer }\end{array}$ & $\begin{array}{l}\text { Very fine to coarse } \\
\text { grained } \\
(0.06-1,2)\end{array}$ & $\begin{array}{l}\text { Whitish- } \\
\text { grey }\end{array}$ & Siliceous-clay & III \\
\hline & \multirow[t]{2}{*}{$\begin{array}{l}\text { Middle } \\
\text { Turonian }\end{array}$} & \multirow[t]{2}{*}{ Długopole } & $4 \mathrm{D}$ & $\begin{array}{l}\text { NE quarry } \\
\text { bank }\end{array}$ & $\begin{array}{l}\text { Very fine to coarse } \\
\text { grained } \\
(0.05-0.8)\end{array}$ & $\begin{array}{l}\text { Grey with } \\
\text { yellow }\end{array}$ & $\begin{array}{l}\text { Clay-siliceous, } \\
\text { sometimes clay- } \\
\text { ferruginous }\end{array}$ & IV \\
\hline & & & $5 \mathrm{D}$ & $\begin{array}{l}\text { NW quarry } \\
\text { bank }\end{array}$ & $\begin{array}{l}\text { Very fine to coarse } \\
\text { grained }(0.05-1)\end{array}$ & $\begin{array}{l}\text { Grey with } \\
\text { yellow }\end{array}$ & Clay-siliceous, & IV \\
\hline
\end{tabular}


climate, with no additional influence of salts in the atmosphere.

\section{Pore structure as a factor determining weathering processes}

The works of many authors emphasize the importance of rock porosity and pore size distribution as determinants of rock weathering (Andriani and Walsh 2003; Fitzner and Kownatzki 1991; Ingham 2005; Ruedrich et al. 2011). Moreover, the porosity and the degree of cementation essentially determine rock mechanical properties (Siegesmund et al. 2011). A large spectrum of methods determining porosity parameters is used. Fitzner and Basten (1992) cross-linked different methods, such as MIP, digital image analysis and nitrogen sorption in order to characterize pore size distribution.

The main factors determining the impact of partial water saturation on rock strength are, first and foremost, the pore radii distribution and the matrix mineralogy, and, secondly, the amount of cement (Demarco et al. 2007). Depending on the capillary properties of porous rocks, the processes of wetting, drying, transport of water and aqueous salt solutions consequently follow, thus causing the destruction of rock. Therefore, not only chemical and mineral rock composition and the type of corrosive agents, but also effective porosity affect the water-soluble salts migration in a significant way. Damaging effects of salt depend on the shape, size and number of pores which are available for liquids, vapours and gases (Skibiński 1985). In the processes of wetting and drying, water and salt solutions are easily transported in the real macropores (with diameters of $10^{-6}$ to $10^{-4} \mathrm{~m}$ ) and larger. As a result of chemical reactions in the rock pores, chemical compounds are formed that increase their volume during crystallization, causing rock disintegration.

Analysis of pore space is one of the important methods useful for the classifying quartz-rich sandstone material (Götze et al. 2007; Fitzner 1988). Fitzner and Kownatzki (1991) made the attempts to determine the susceptibility to weathering of the most famous types of sandstones in Germany, by combining the macroscopic observations, simulation tests of salt crystallization $\left(\mathrm{Na}_{2} \mathrm{SO}_{4}\right)$ and freezing tests, in correlation with the pore size distribution. Simulation tests have shown close conformity to the behaviour of these rocks in the buildings. In conclusion, the authors found that the distribution of pores in the rock and the total porosity significantly influence the destruction of rocks, due to the maximum pressure of ice crystallization in the largest pores. Also, salt crystallization starts in the pores of the largest diameters, and the delivery of new portions of water-soluble salts takes place through pores with smaller diameters.
The important role in the harmful effects of water-soluble salts is that it exerts an effect on the porosity of internal and external surface layer, formed, after some exposure time, in the rock material. These changes are seasonal, associated with fluctuations in temperature and air humidity. The salt movement to the rock surface causes a temporary decrease in the porosity of the outer zone. The following leaching of salt contributes to increased porosity of this zone, in comparison with deeper parts of the rock.

Robertson (1985) draws attention to the role of the narrowed rock pore entrances, the so called ink-bottle. The observations have proved that the greater the amount of ink-bottle pores in the rock, the more rock is susceptible to destruction. Fitzner and Snethlage (1982) also demonstrated that frost damage is associated with the existence of small pores in contact with coarser pores.

It should be noted, however, that the rocks with a high proportion of small pores exhibit lower compressive strength in comparison with the rocks containing predominantly large pores (Winkler 1975). The greatest compressive strength indicates even-grained sandstone samples, which is associated with relatively low total porosity.

Concerning hydric dilatation, swelling of natural stones results from "capillary pressures" set up in the pore system and in cracks of small dimension. The swelling is strongly influenced by the pores size distribution (Felix 1983). Hydric dilatation may have an influence on deterioration, also due to freeze-thaw cycles. The movement of the grain structure, occurring as a consequence of the weathering phenomena, may provide open space, where ice crystals may form (Snethlage and Wendler 1997). During the deterioration, the pore structure modification may be a precursor to the more substantial macro-deterioration. The pore size distribution is influenced by the weathering process, as a consequence of degradation of original rock structure. The modification may occur as a result of the following processes:

- propagation of the new cracks, initiated by internal fluid pressure induced by freeze-thaw cycles,

- pore enlargement connected to the loose debris (generated by the break-up of grain contacts) redistribution within the pore structure, which improves the pore connectivity without changing the total pore volume,

- dissolution, which affects mainly limestone or sandstones with carbonate cement,

- pore compression.

In the overwhelming number of cases, the initial porosity increases as a consequence of dissolution of the rock components, leading to the opening of substantial number of isolated pores and increasing the reactive surface area (Colon et al. 2004). 


\section{Methods}

The modelling of accelerated weathering was conducted in Chamber for Ageing Acceleration (CAA), in the laboratory of Silesian University of Technology (Gliwice, Poland). Samples were put into the chamber, where some weather circumstances were simulated (insolation, rain and frost) (Fig. 2).

The "Chamber of Sun" simulates insolation in wavelength spectrum of 70-400 nm (halogen lamps), as well as ultraviolet radiation with a wavelength of 254 and $185 \mathrm{~nm}$. The temperature on the samples surface is restricted to maximum $+70{ }^{\circ} \mathrm{C}$.

The "Chamber of Rain" enables water spraying on the samples' surface. The amount of water sprayed is about $15 \mathrm{l} / \mathrm{m}^{2} \mathrm{~h}$, with the temperature of $16 \pm 2{ }^{\circ} \mathrm{C}$.

The "Chamber of Frost" simulates winter circumstances. The minimal temperature on the sample surface is $-20 \pm 2{ }^{\circ} \mathrm{C}$.

The defrosting process is performed in the environment of the laboratory room, in the intermediate position between the Chamber of Frost and the Chamber of Sun. The conditions of the laboratory are as follows: temperature of $18 \pm 2{ }^{\circ} \mathrm{C}$ and the air relative humidity $\varphi=50 \pm 10 \%$.

Duration of each cycle is $24 \mathrm{~h}$. The central chamber with the attached rock samples is rotating through the chambers of Sun, Rain and Frost, returning to the neutral position of the laboratory room. The examined samples

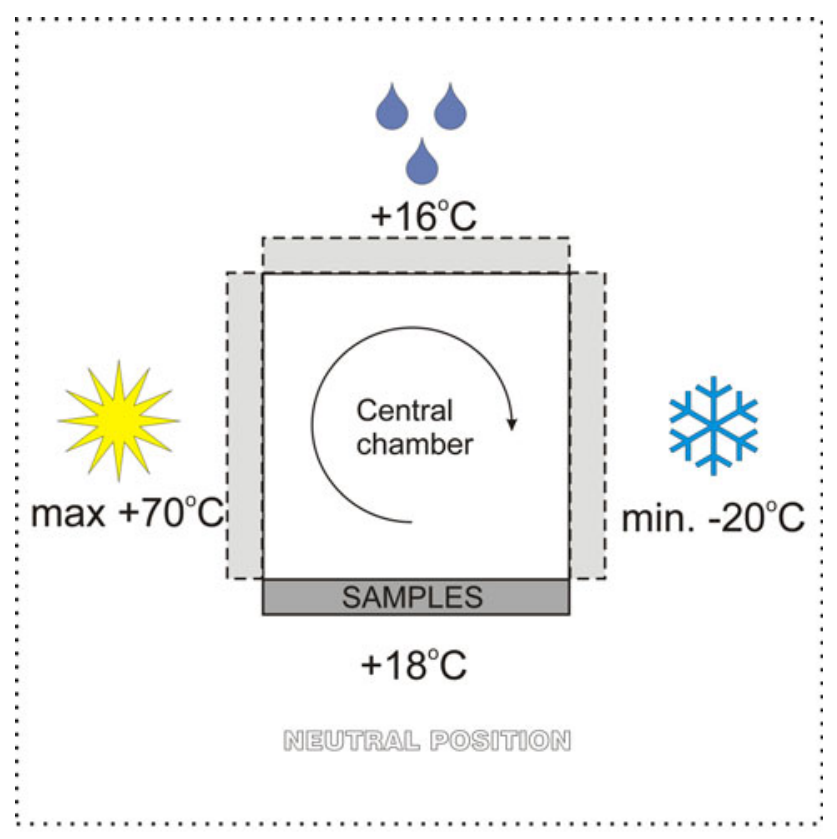

Chamber for Aging Acceleration

Fig. 2 The scheme of Chamber for Ageing Acceleration (top view) were subjected to 100 cycles of rotation $(50+50)$. After 100 cycles some of the samples were completely destroyed, so we decided to end the experiment at this stage.

The samples were cut into plates of the dimensions of about: $100 \times 100 \times 25 \mathrm{~mm}$. The samples were fitted on the wall of the rotational central chamber, on the galvanized sheet frame. The isolation between the samples and the internal part of the chamber was foamed polystyrene plate.

After completing 50 and next 100 rotation cycles, the samples were subjected to petrographic macroscopic observations in order to register ongoing changes on the samples surface. The samples were weighed and the proportional weight increase or decrease was calculated.

The microporosity analysis by mercury porosimetry was performed on the samples before, and after the experiment. The porosimetric measurement with use of MIP was carried out at the Oil and Gas Institute in Kraków (Poland) on Autopore 9220 Micrometrics Injection Porosimeter.

The samples after the experiment were also observed by SEM microscope JSM 630 with EDS Oxford $(20 \mathrm{kV})$.

\section{Sandstone classification on the basis of porosimetric measurements}

In the case of the analysed Lower Silesia quader sandstones, the pore space characteristic is different from the other types of Polish sandstones (the Carpathian or from Holy Cross Mountains region) (Labus 2008). Transitive pores of diameters in the range from $10^{-8}$ to $10^{-7} \mathrm{~m}$ compose $1 \%$ of pore structure. This is the reason of relatively high weathering resistivity of quader sandstones. Nevertheless in this big group of rocks, the weathering resistivity still differs, in respect of the pore dimensions and mineral composition of grains and cement of the stone. One of the additional parameters, making possible to distinguish the classes, was the hysteresis value $(H)$ between the curves of increasing and decreasing pressure (the example of hysteresis is shown in Fig. 7).

Based on the analysis of MIP curves, an attempt was undertaken to identify the weathering-resistance classes within the examined quader sandstones. The curves were fitted to van Genuchten's empirical capillary pressure-saturation function (van Genuchten 1980), which provides a good fit to the data (Bloomfield et al. 2001; Labus 2008, 2011).

The van Genuchten function is expressed as:

$P=P_{o}\left(S_{e}^{-1 / m}-1\right)^{1-m}$,

where $P$ is the macroscopic capillary pressure, $P_{\mathrm{o}}$ is the characteristic pressure of the medium, $m$ is the pore size distribution index, $S_{\mathrm{e}}$ is the normalized wetting fluid saturation, defined as: 
$S_{e}=\frac{S_{w}-S_{r}}{S_{m}-S_{r}}$

where $S_{\mathrm{w}}$ is the wetting phase saturation, $S_{\mathrm{r}}$ is the residual saturation of non-wetting phase, and $S_{\mathrm{m}}$ is the fluid content at natural saturation.

The van Genuchten function is often used to describe the soil water retention curve of unsaturated soils and fractured rock. However, $m$ is an empirical parameter, in pedology attempts were undertaken to determine the van Genuchten model parameter $m$ from the fractal dimension (Ghanbarian-Alavijeh et al. 2010).

The capillary pressure-saturation curves were fitted to the van Genuchten equation using the standard least squares minimization routine. For the uni-modal curves, the fit to the experimental data was sufficiently satisfying $\left(R^{2}=0.98\right)$; whereas for the bimodal curves, the fit was lower (e.g. $R^{2}=0.87$ ). For the samples of bimodal curves, the final intrusion volume was slightly underestimated by the van Genuchten function. As a result of the fitting routine, for each sample four parameters are calculated: $D_{\text {Po, }}$ $m, S_{\mathrm{r}}$ and $S_{\mathrm{m}}$. The most essential ones, enabling a quantitative comparison between the sampled rocks, were $D_{\text {Po }}$, the equivalent pore-throat sizes for characteristic pressure $P_{\mathrm{o}}$ and $m$, the pore size distribution index. Index $m$ was ranged between 0.17 and 0.84 , and the equivalent porethroat size $D_{\text {Po }}$ was strongly diversified between 0.18 and $27.3 \mu \mathrm{m}$. Based on the parameterization, with the van Genuchten function of cumulative capillary pressure saturation curves, by plotting the parameter $m$ versus $D_{\mathrm{Po}}$, the points representing samples could be grouped. In the plot (Fig. 3), it was possible to distinguish four groups of the analysed sandstones. The points represented all the examined samples; however, among them some samples (24) were selected and further subjected to the modelling of the accelerated weathering (CAA).

The characteristic of the sandstone samples belonging to the evolved groups is presented below and in Table 2 .

Group I $\left(m: 0.17-0.45 ; D_{\mathrm{Po}}: 0.18-4.00 \mu \mathrm{m}\right)$ was represented by even-grained rocks, of comparatively uniform pore size distribution ranging from 0.1 to $100 \mu \mathrm{m}$. Total porosity was in the wide range from 10.81 to $23.45 \%$. The amount of rock cement varied (1-22\%), as well as sorting (0.66-1.83). The cement in sandstones belonging to group I was siliceous-argillaceous, argillaceous-siliceous or argillaceous-siliceous-ferruginous.

In group II ( $\left.m: 0.72-0.84 ; D_{\mathrm{Po}}: 20.01-27.30 \mu \mathrm{m}\right)$ the cumulative curves were uni-modal, with the domination of real macropores, mostly in the range of $10-100 \mu \mathrm{m}$ (Table 2). This type of pore area favoured water absorption, but the water was easy to remove. So, the time of reaction with aqueous solutions of salts in pores of the rock was limited to wet weather. The total porosity of rocks in group II was relatively high (20.65-31.13\%). Cement was mostly siliceous-argillaceous, and the grain contacts were long, or rarely: concave-convex.

Sandstones which were rated as group III ( $m$ : 0.50-0.76; $D_{\text {Po: }}$ 9.66-21.51 $\mu \mathrm{m}$ ) had bimodal capillary pressure saturation curves. The porosimetric cumulative curves showed bimodal shape-histograms of pore diameters distribution
Fig. 3 Grouping the sandstone samples into classes based on $m$ and $D_{\text {Po }}$ parameters cross-plot

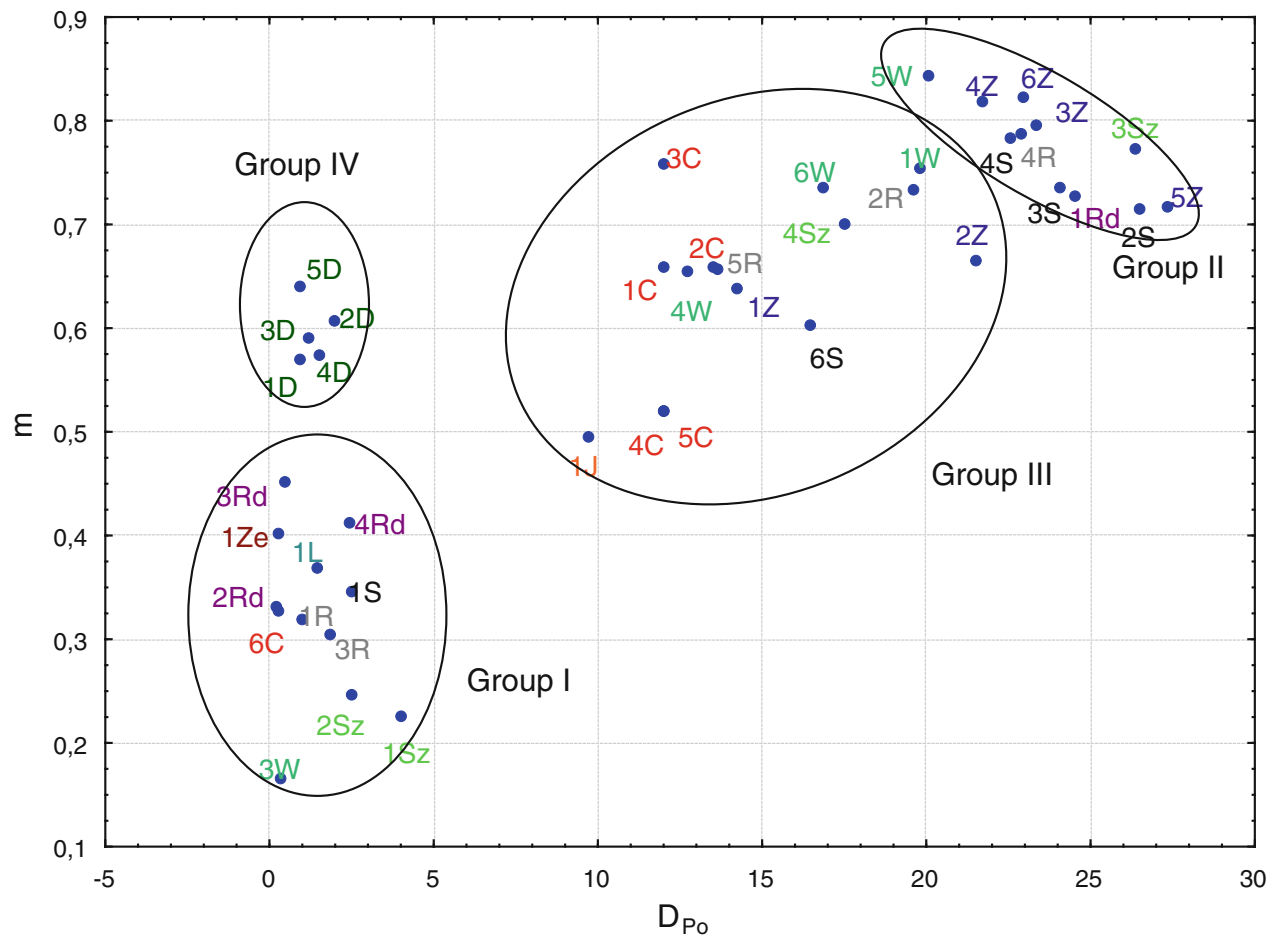


Table 2 Pore area characteristic in the weathering resistivity groups (after Labus 2011, changed)

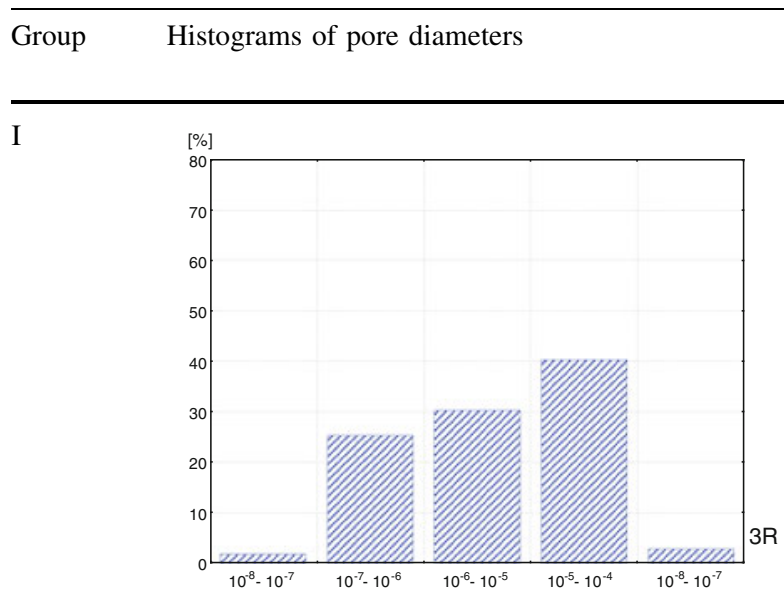

Example of pore area morphology SEM

Hysteresis $(H)$ (magnification 200 $\times$ )

II
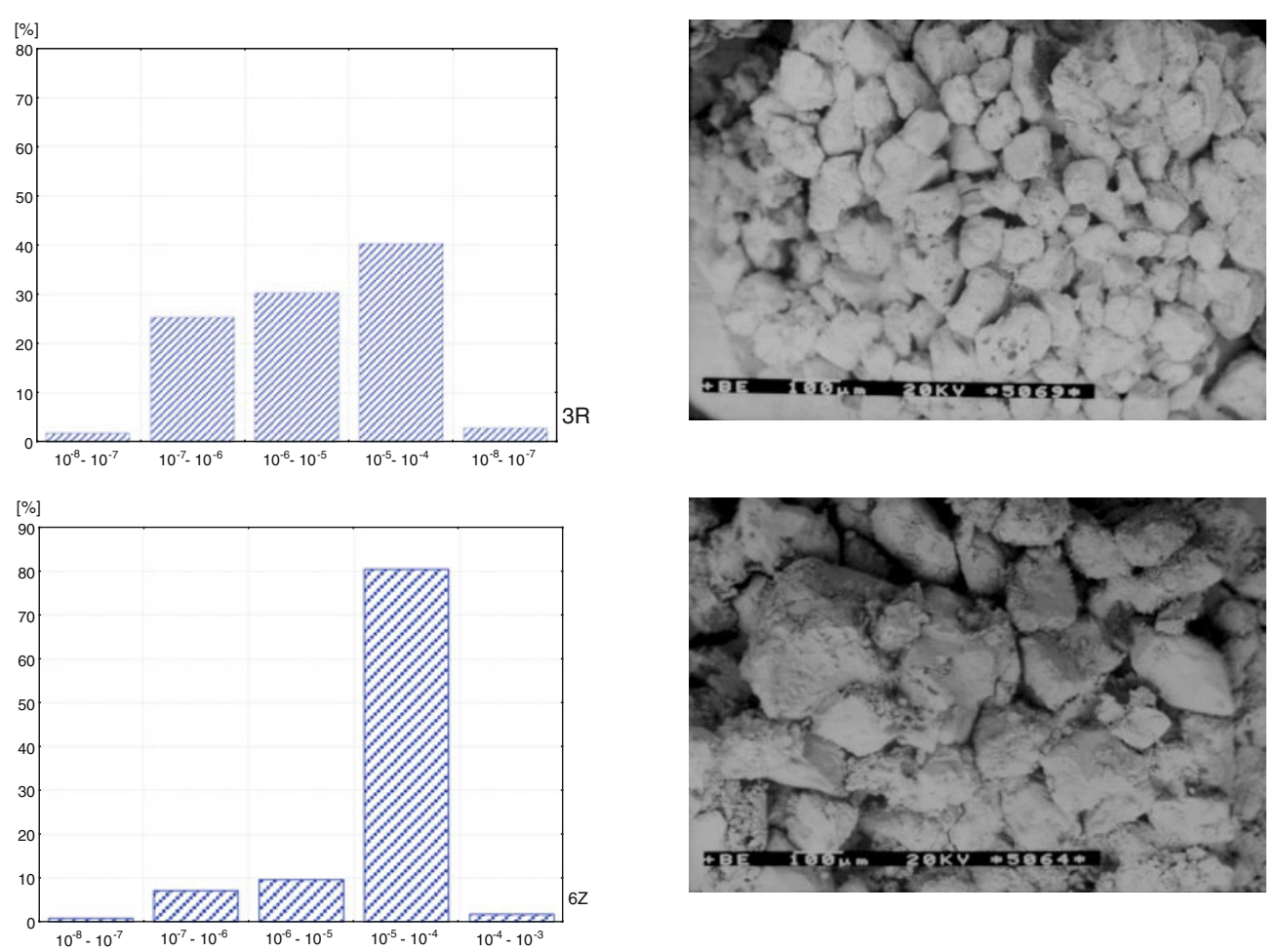

$17-76$

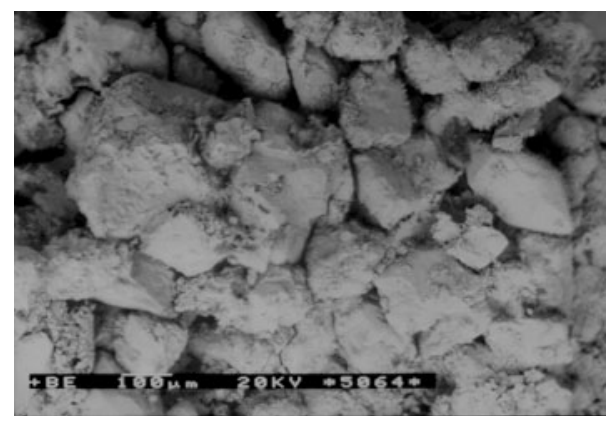

6-9

III
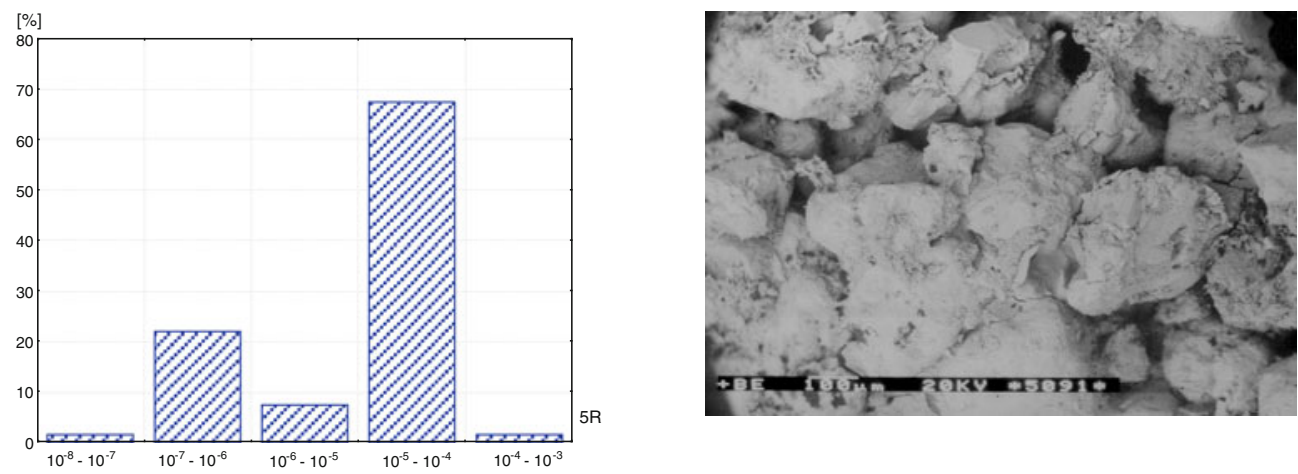

$10-29$

IV

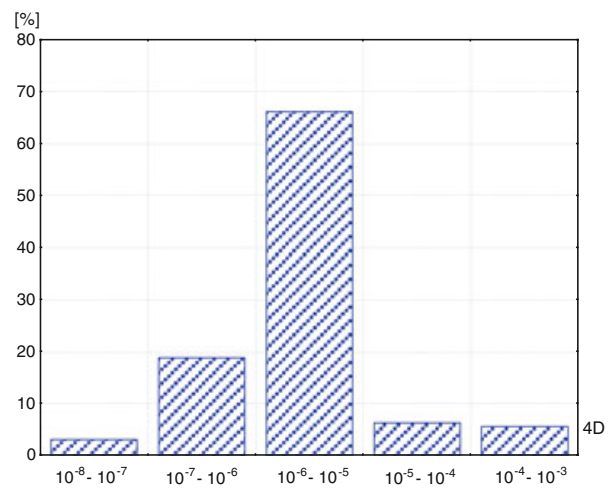

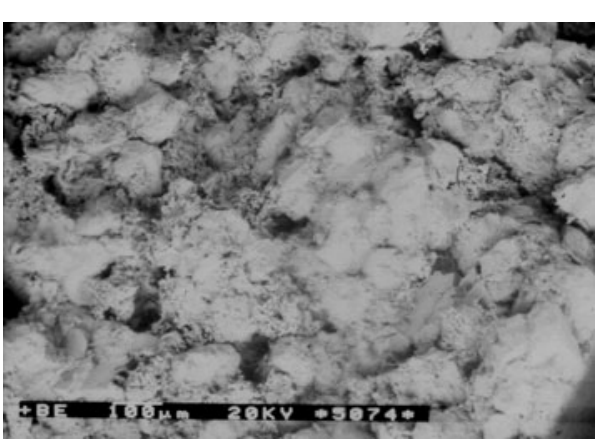

$71-86$ 
(in Table 2) revealed two uneven maxima in the range from 10 to $100 \mu \mathrm{m}$ and 0.1 to $1 \mu \mathrm{m}$. The total porosity was in the range of $16.27-26.66 \%$.

In the case of group IV $\left(m: 0.57-0.64 ; D_{\mathrm{Po}}\right.$ : $0.87-1.93 \mu \mathrm{m})$, the cumulative curves were, similar to group III, bimodal. As opposed to group III, the dominating pores were macropores in range from 1 to $10 \mu \mathrm{m}$. Total porosity was relatively low (12.69-15.27\%).

\section{Accelerated weathering experiment}

Out of the examined samples, 24 were selected to be tested in the accelerated weathering experiment in CAA. Group I was represented by samples: 1R, 3R, 1S, 3W, 6C, 1Ze; group II by samples: $2 \mathrm{~S}, 4 \mathrm{~S}, 3 \mathrm{Sz}, 5 \mathrm{~W}, 3 \mathrm{Z}$; group III by samples: 5R, 4Sz, 2C, 3C, 5C, 1W, 1Z, 2Z, 1J; and group IV by samples $4 \mathrm{D}$ and $5 \mathrm{D}$.

At the first stage of the experiment, weighing was performed on the quadrels of rock samples of natural humidity. This weight was considered as the starting point (100\%). After 2 days of drying in temperature of $110^{\circ} \mathrm{C}$, the weight of the samples under dry conditions was determined. The mass loss, as a result of drying, did not exceed $0.5 \%$. In a 2-month time, after completing 50 cycles, conducted in CAA, the weight of the rock samples changed (Fig. 4). In most cases it increased (maximally to $1.18 \%$ ) as a result of absorption of "rain" water. In some cases (samples 1J, 3W, 4W, 2S and 6S), the mass decreased in the range from 0.05 to $4.05 \%$ as a result of crushing (Fig. 5).
After completing stage II of the experiment (the next 50 cycles in CAA), the weight of most samples increased. The proportional increase reached even $4.77 \%$ (sample $5 \mathrm{~W}$ ) and $5.82 \%$ (sample $2 \mathrm{~S}$ ). In some cases, significant weight loss was noticeable, which was the effect of samples disintegration. Samples $4 \mathrm{~W}$ and $6 \mathrm{~S}$ were destructed. In case of samples $3 \mathrm{Sz}, 4 \mathrm{Sz}$ and $1 \mathrm{~J}$, the weight loss was minor $(0.05-3.28 \%)$, an outcome of grain loss on the sample edges.

Specific observations carried out on the examined samples are presented below.

Szczytna sandstone samples ( $3 \mathrm{Sz}$ and $4 \mathrm{Sz}$ ) were slightly changed. In case of sample $3 \mathrm{Sz}$ the ferruginous discoloration stains appeared. Sample $4 \mathrm{Sz}$ was chipped at the edges, which was the reason of the mass loss of $0.95 \%$.

Długopole sandstone samples (4D and 5D) revealed quite good weathering resistivity. The mass loss in the last stage of the experiment was very small (0.20-0.27\%). Only the slight discolouration, as a result of ferruginous minerals oxidation, was observed. The samples became butterscotch in colour.

Jerzmanice sandstone (1J) was poorly sorted with conglomerate sandstone of low coherency. After stage I of the experiment (50 cycles) in CAA, there was noticeable mass loss of $2.03 \%$. At the end of the experiment, the mass loss increased to $5.66 \%$ due to partial sample disintegration.

Czaple sandstone was represented by samples $2 \mathrm{C}, 3 \mathrm{C}$, $5 \mathrm{C}$ and $6 \mathrm{C}$. In samples $2 \mathrm{C}, 3 \mathrm{C}$ and $5 \mathrm{C}$ the visible changes are: grains and cement loss. As a result, in stage II of the experiment the weight of these samples decreased in the range of $0.88-1.38 \%$. The most resistant sandstone was
Fig. 4 Sample mass changes after the experiment in Chamber for Ageing Acceleration (CAA): $I$ the beginning of the experiment, Ia after a 2-day drying, $I I$ after 50 cycles in the CAA chamber, IIa after a 4-day drying, $I I b$ the beginning of the stage II in CAA chamber, III after 100 cycles in the CAA chamber, IIIa after 7 days of drying. Samples are marked with colours according to the weathering-resistive groups: $I$ black, $I I$ red, $I I I$ green, $I V$ blue

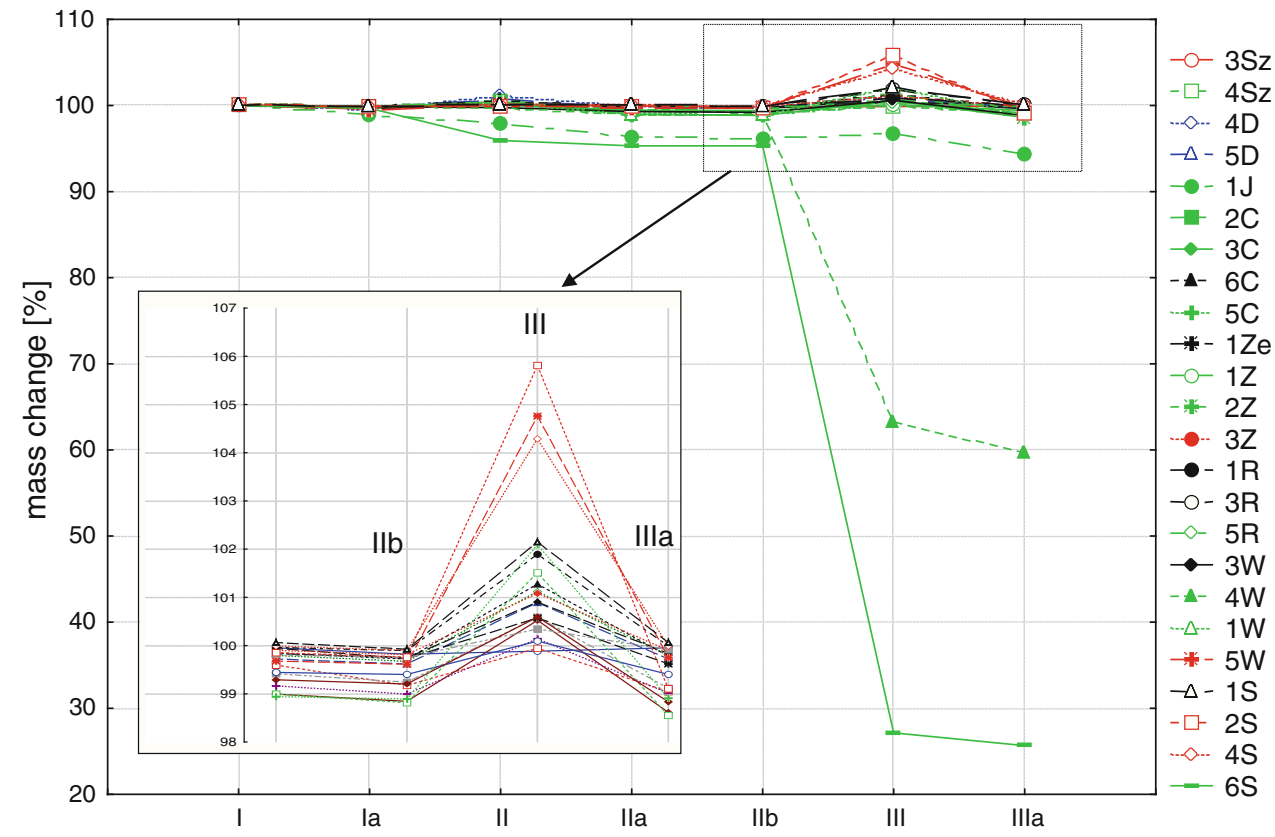




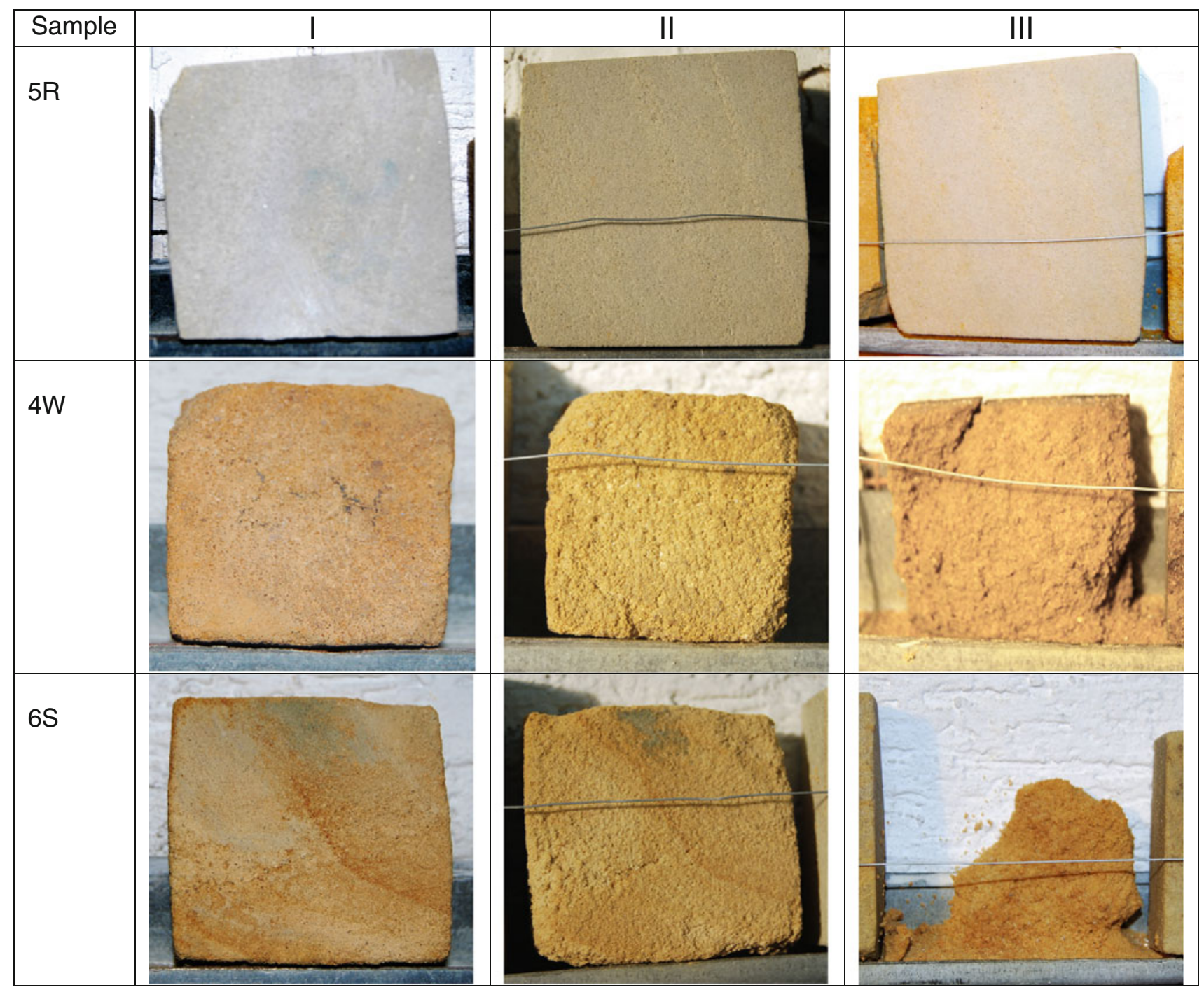

Fig. 5 The examples of sandstones behaviour in the process of the weathering experiment (stages $I, I I, I I I$ of the experiment)

sample $6 \mathrm{C}$ of mass loss of $0.21 \%$, without any noticeable macroscopic changes.

Żeliszów was represented by only one sample 1Ze, which proved to be highly weathering-resistant one. The mass loss after the experiment was very slight $(0.37 \%)$ and there were no macroscopic visible changes.

Żerkowice deposit was represented by samples $1 \mathrm{Z}, 2 \mathrm{Z}$ and $3 Z$. Samples $1 Z$ and $2 Z$ were strongly deteriorated. The ferrous cement was oxidised in the weathering process, and in consequence, the colour of the rock was changed. In case of $2 \mathrm{Z}$ sample, the mass loss was quite severe $(1.44 \%)$ due to grains loss at the chipped edges. In the case of sample $3 Z$, slight macroscopic changes were noticed, and the mass loss was not significant: $0.09 \%$. After stage II of the experiment in CAA, this sample showed high absorption capacity.

Rakowiczki sandstone samples $1 \mathrm{R}, 3 \mathrm{R}$ and $5 \mathrm{R}$ seemed to be weathering proof. After the experiment, the colour was not changed. There was no visible grain or cement loss, and the edges of the sample quadrels were sharp. The mass loss was not significant (Fig. 4).

Wartowice deposit was represented by samples $1 \mathrm{~W}$, $3 \mathrm{~W}, 4 \mathrm{~W}$ and $5 \mathrm{~W}$, the behaviour of which was well differentiated. Sample $5 \mathrm{~W}$ seemed to be the most resistant one, as the mass loss after the experiment was small $(0.24 \%)$. But the absorption capacity after stage II of the experiment was high $(4.77 \%$ ), which was probably caused by visible lamination of the rock. Similar behaviour was shown in case of sample $1 \mathrm{~W}$, the absorption capacity of which after stage II of the experiment was $2.10 \%$, probably also due to rock lamination. In this case; however, the deterioration was very severe. Even after stage I of the experiment, selective weathering was visible. After stage II, the mass loss was significant $(1.08 \%)$, the sample edges were rounded, and the ferruginous stripes originated. Sample $4 \mathrm{~W}$ after stage I of the experiment (50 cycles) was 
seriously selectively weathered, with the mass loss of $1.1 \%$. After stage II, the sample was nearly entirely destroyed (Fig. 5).

Żerkowice-Skała sandstone revealed good weathering resistance. In the case of sample $1 \mathrm{~S}$, there were no visible macroscopic changes. In samples $2 \mathrm{~S}$ and $4 \mathrm{~S}$, the changes were nearly invisible; however after stage II of the experiment (100 cycles), the mass of the samples increased (by 4.30 and $5.82 \%$, respectively), due to water absorption. Sample 6S, which was laminated, became disintegrated even in stage I of the experiment. After 50 cycles in CAA, the mass of sample $6 \mathrm{~S}$ decreased by $4.69 \%$, whereas after 100 cycles it was completely destroyed (Fig. 5).

\section{Porosity and the pore space properties}

After completing the experiment (100 cycles in CAA), the samples which were not entirely destroyed (as samples $6 \mathrm{~S}$ and $4 \mathrm{~W}$ ) were again subjected to the porosimetric measurement (MIP) in AutoPore 9220. Table 3 presents some porosimetric parameter values before and after the experiment. Threshold diameter $d_{\mathrm{th}}$ and hysteresis $H$ were the parameters interpreted from the semilog mercury injection plot of the pore-throat size $(\mu \mathrm{m})$ against the percentage pore space saturated with mercury.

As a result of the ongoing processes in CAA, the values of total porosity $\left(\Phi_{\mathrm{o}}\right)$ and effective porosity $\left(\Phi_{\mathrm{e}}\right)$ usually increased. The reason for the porosity increase is probably microcracks formed as a result of frost attack. The phenomenon resulted in the increase of the specific surface of the pores and the increase of the mean pore diameter.

The results of the porosity measurements, however, should be interpreted with caution, due to the inhomogenities of the tested samples, as the MIP measurements were performed on different small samples from the same material before and after the experiment.

The decrease of the value of effective porosity was applied to samples $3 \mathrm{Sz}, 3 \mathrm{Z}$, and $3 \mathrm{~W}$, (belonging to group II) and samples $4 \mathrm{Sz}, 1 \mathrm{~J}$, and $2 \mathrm{Z}$ (belonging to group III) (Fig. 6). These samples were specific as they included, originally, a significant amount of clay minerals. Hence,

Table 3 Porosity of the sandstone samples before and after the experiment of ageing acceleration

\begin{tabular}{|c|c|c|c|c|c|c|c|c|}
\hline \multirow[t]{3}{*}{ Sample } & \multicolumn{4}{|c|}{ Before the experiment } & \multicolumn{4}{|c|}{ After the experiment } \\
\hline & \multicolumn{2}{|l|}{ Porosity } & \multirow{2}{*}{$\begin{array}{l}\text { Threshold } \\
\text { diameter } \\
d_{\text {th }}(\mu \mathrm{m})\end{array}$} & \multirow{2}{*}{$\begin{array}{l}\text { Hysteresis } \\
H(\%)\end{array}$} & \multicolumn{2}{|l|}{ Porosity } & \multirow{2}{*}{$\begin{array}{l}\text { Threshold } \\
\text { diameter } \\
d_{\text {th }}(\mu \mathrm{m})\end{array}$} & \multirow{2}{*}{$\begin{array}{l}\text { Hysteresis } \\
H(\%)\end{array}$} \\
\hline & $\Phi_{\mathrm{o}}(\%)$ & $\Phi_{\mathrm{e}}(\%)$ & & & $\Phi_{\mathrm{o}}(\%)$ & $\Phi_{\mathrm{e}}(\%)$ & & \\
\hline $3 \mathrm{Sz}$ & 18.00 & 18.10 & 50 & 7 & 15.18 & 15.03 & 25 & 57 \\
\hline $4 \mathrm{Sz}$ & 17.64 & 17.47 & 60 & 18 & 14.52 & 14.24 & 30.2 & 22 \\
\hline $4 \mathrm{D}$ & 14.06 & 13.10 & 10 & 74 & 16.02 & 13.93 & 8 & 70 \\
\hline $5 \mathrm{D}$ & 12.69 & 12.90 & 4 & 78 & 15.60 & 14.18 & 4 & 75 \\
\hline $1 \mathrm{~J}$ & 16.27 & 15.99 & 50 & 29 & 13.32 & 12.57 & 50 & 47 \\
\hline $2 \mathrm{C}$ & 23.80 & 22.06 & 70 & 22 & 27.62 & 25.11 & 90 & -22 \\
\hline $3 \mathrm{C}$ & 23.04 & 22.99 & 90 & 19 & 25.87 & 26.13 & 90 & 17 \\
\hline $5 \mathrm{C}$ & 25.26 & 20.74 & 60 & 18 & 24.59 & 24.59 & 50 & 16 \\
\hline $6 \mathrm{C}$ & 15.08 & 14.36 & 8 & 61 & 20.19 & 17.26 & 50 & 31 \\
\hline $1 \mathrm{Ze}$ & 19.79 & 19.08 & 20.5 & 46 & 21.08 & 19.52 & 25.4 & 49 \\
\hline $1 \mathrm{Z}$ & 23.48 & 23.02 & 50 & 28 & 26.53 & 26.01 & 50 & 15 \\
\hline $2 Z$ & 23.90 & 23.43 & 45 & 10 & 22.86 & 22.63 & 50 & 6 \\
\hline $3 Z$ & 25.16 & 25.16 & 45 & 7 & 25.24 & 24.27 & 50 & 12 \\
\hline $1 \mathrm{R}$ & 17.96 & 17.78 & 30.3 & 34 & 19.97 & 19.97 & 30.2 & 36 \\
\hline $3 R$ & 19.35 & 19.16 & 30.2 & 18 & 22.57 & 22.57 & 50 & 9 \\
\hline $5 \mathrm{R}$ & 23.38 & 24.61 & 35.2 & 14 & 25.44 & 25.44 & 40 & 6 \\
\hline $1 \mathrm{~W}$ & 18.62 & 16.48 & 45 & 10 & 22.59 & 22.59 & 40.2 & 16 \\
\hline $3 \mathrm{~W}$ & 18.20 & 17.67 & 90.3 & 17 & 20.78 & 20.17 & 90.1 & 9 \\
\hline $5 \mathrm{~W}$ & 25.18 & 24.93 & 30 & 6 & 23.72 & 23.72 & 90 & 6 \\
\hline $1 \mathrm{~S}$ & 23.45 & 22.55 & 30.2 & 25 & 35.15 & 35.15 & 90 & 9 \\
\hline $2 \mathrm{~S}$ & 27.60 & 26.04 & 50 & 6 & 30.40 & 30.40 & 50 & 4 \\
\hline $4 \mathrm{~S}$ & 26.17 & 24.23 & 40 & 7 & 25.41 & 25.41 & 50 & 6 \\
\hline
\end{tabular}

$d_{\text {th }}$ threshold diameter corresponds to the pressure which admits the mercury intrusion to the pores inside the specimen, through the smallest size pores. After passing the "threshold diameter" a steep increase of the intruded mercury volume is observed 
Fig. 6 Changes of effective porosity in the sandstone samples after the accelerated weathering simulation experiment: $P 1$ porosity value before the experiment, $P 2$ porosity value after 100 cycles in Chamber for Ageing Acceleration

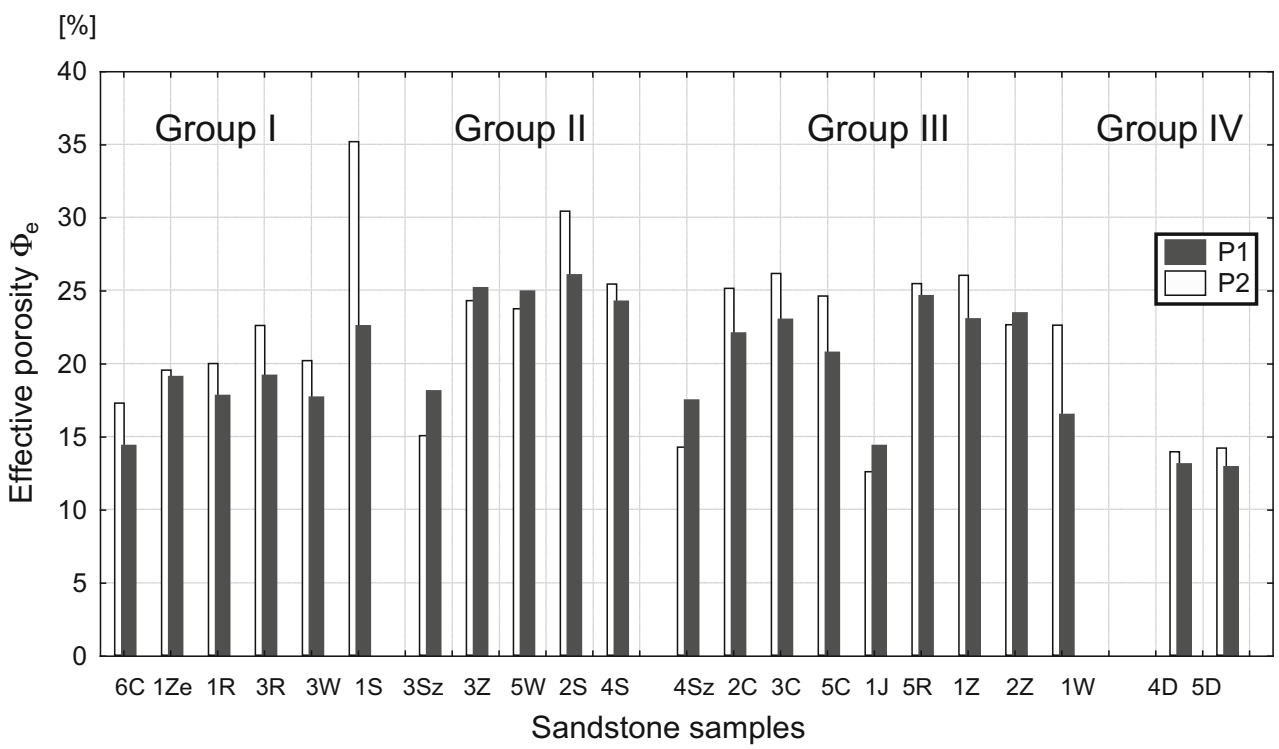

the lowered value of effective porosity in these samples after the experiment could be explained by the water absorption of clay minerals in cement, as a consequence of simulated rainfall.

When analysing capillary pressure curves, it could be stated that in the case of sandstones belonging to group I, the shape of the curves seemed to be very similar before and after the experiment (Fig. 7a). When the effective porosity after the experiment increased by a small value, the cumulative curves were nearly overlaid (sample 1Ze).

When the porosity increased by a few percentage (2-3.4 \%), the number of macropores in the range from 10 to $50 \mu \mathrm{m}$ grew (samples $1 \mathrm{R}$ and $3 \mathrm{~W}$ ), and the hysteresis value dropped, which indicated that the number of inkbottle pores decreased (Fig. 7b). When the pore area increased, the pore fluids could easily flow.

The sandstones which belonged to group II showed very small value of hysteresis (e.g. sample 4S). The most characteristic was the fact that after the experiment in CAA, hysteresis was stable, not extending $12 \%$. In this group of rocks, the effective porosity dropped insignificantly (about $1 \%$ ) after the weathering acceleration experiment. The exception was sample $3 \mathrm{Sz}$, the hysteresis value of which $(57 \%)$ motivated us to rate this sample as the least weathering resistant.

Within group III the shapes of cumulative curves before and after the experiment were similar. Usually, the bimodal character of pore diameters distribution of the curve was maintained. The most interesting was the shape of the extrusion cycle. In case of samples $4 \mathrm{Sz}$ and $2 \mathrm{C}$ (Fig. 7c), the extrusion curve was situated below the primary (intrusion) curve, which was the evidence of the presence of ink-bottle pores in the rock. The choke points appeared as a result of salt crystallization or clay minerals water absorption. This phenomenon may also be the reason for effective porosity decrease after the experiment.

Regarding the behaviour of samples belonging to group IV, it could be stated that the shapes of the cumulative curves before and after the experiment were congruent. Effective porosity increased by only $1 \%$, which was connected to microcracks occurrence. In consequence, the number of pores in the range from 0.5 to $2 \mu \mathrm{m}$ increased (Fig. 7d).

\section{Sandstone degradation}

The experiment performed in CAA showed the differences in the behaviour of the sandstone samples. The high weathering resistance was shown in the samples: $1 R, 3 R$, $5 \mathrm{R}, 1 \mathrm{~S}, 6 \mathrm{C}$ and 1Ze. There were no macroscopic changes on the rock surface, regarding colour change or grain loss. The edges of sample quadrels remained sharp, and the mass loss was not significant. As indicated in Fig. 3, the mentioned samples were placed in the area of group I. The exception was sample 5R, belonging to group III.

Considerably high weathering resistance was revealed in samples: $2 \mathrm{~S}, 4 \mathrm{~S}, 3 \mathrm{Sz}, 5 \mathrm{~W}, 3 \mathrm{Z}$, belonging to group II, see Fig. 3. The changes within the rocks samples were not macroscopically visible. After stage I in CAA (50 cycles), the mass changes were insignificant, but after completing stage II (100 cycles) the water absorptivity considerably increased (Fig. 4).

The remaining samples $(4 \mathrm{Sz}, 2 \mathrm{C}, 3 \mathrm{C}, 5 \mathrm{C}, 1 \mathrm{~W}, 3 \mathrm{~W}, 1 \mathrm{Z}$, $2 \mathrm{Z}, 1 \mathrm{~J}, 4 \mathrm{D}, 5 \mathrm{D})$ revealed the lowest weathering resistance. Partial or nearly complete destruction was noticeable as selective weathering, crumbling out of the parts of the rocks due to weight loss. The samples in the last stage of the 

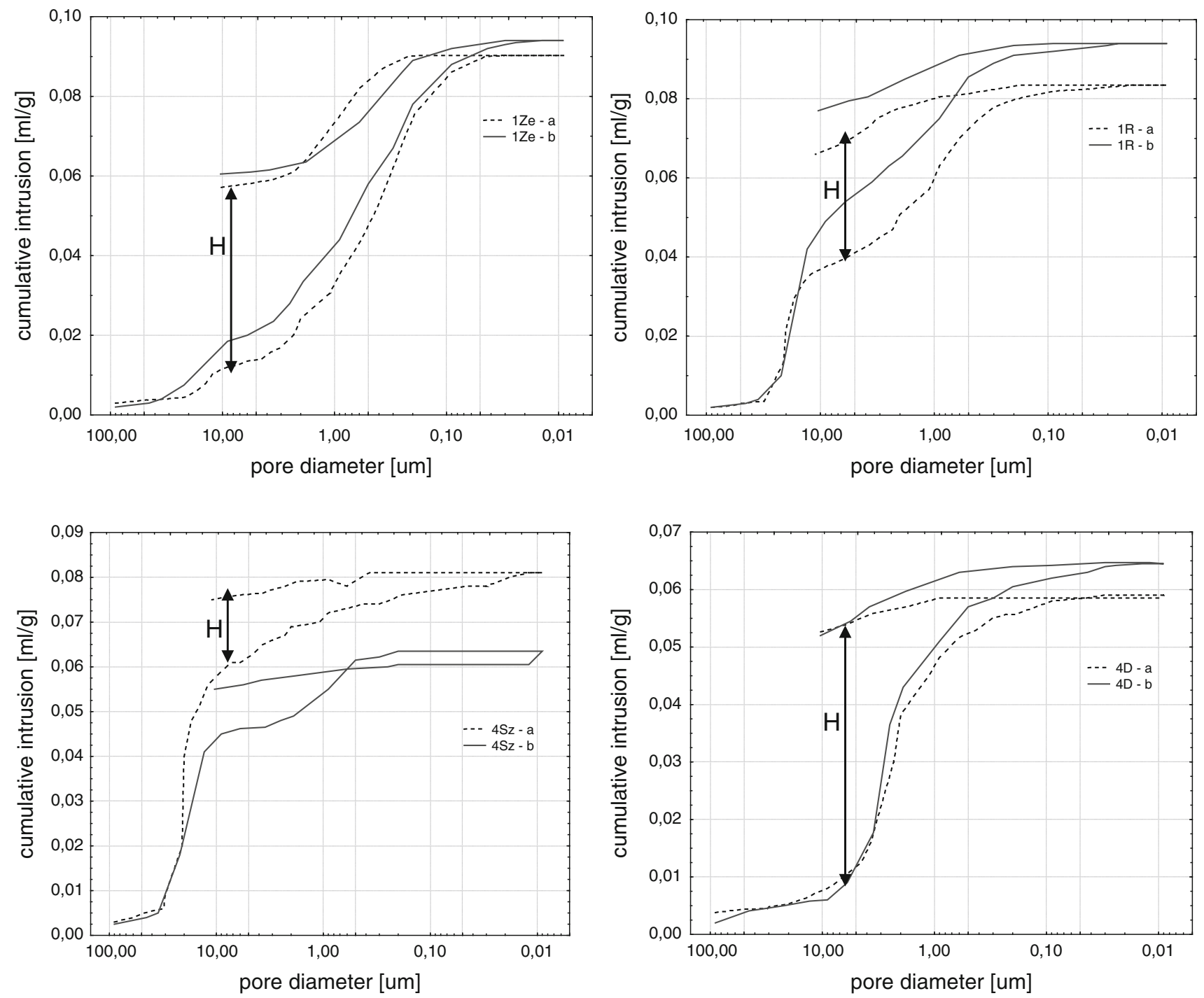

Fig. 7 Intrusion and extrusion porosimetric curves for selected rock samples before (a) and after (b) the experiment. a sample 1Ze, b sample 1R, c sample $4 \mathrm{Sz}$, $\mathbf{d}$ sample $4 \mathrm{D}$

experiment showed high water absorptivity. The examined samples belonged mostly to group III: $4 \mathrm{Sz}, 2 \mathrm{C}, 3 \mathrm{C}, 5 \mathrm{C}, 1 \mathrm{~W}$, $1 \mathrm{Z}, 2 \mathrm{Z}, 1 \mathrm{~J}$. The exceptions were sample $3 \mathrm{~W}$ allocated in Fig. 3 to group I and samples 4D and 5D allocated to group IV. The appearance of low weathering resistance of sample $3 \mathrm{~W}$ was macroscopically visible as crushing and selective weathering, as well as weight loss after the first stage of the experiment. The phenomenon was related to rock lamination with ferruginous matter. Samples 4D and 5D were initially ranked as group IV, regarding the $m / D_{\mathrm{Po}}$ ratio, but taking into account their behaviour, it could be stated that their weathering resistance was very similar to the samples belonging to group III.

In consequence, based on the analysis of the capillary pressure saturation curves, the following groups may be distinguished: group I: high weathering resistant, group II: relatively high weathering resistant, groups III and IV: poor weathering resistant.

The position of the samples which were tested in CAA is shown in Fig. 8. As indicated, the classification parameter $D_{\mathrm{Po}}$ in group III/IV is in a very wide range $(0.87-21.51)$, but the parameter $m$ is contained in a narrower range, from 0.50 to 0.76 .

The high resistance of rocks belonging to group I is mostly determined by: fine-grained fraction and regenerative cement type, which was proved by the microscopy analysis. The important feature was also the concave-convex type of inter-granular contacts. A very important factor was uniform pore size distribution ranging from 0.1 to $100 \mu \mathrm{m}$.

Group II was represented by coherent sandstones of quite high weathering resistance, in spite of their high total 
Fig. 8 The position of the samples which were tested in CAA on $m$ and $D_{\text {Po }}$ parameters cross-plot. Red labels very high weathering resistant, blue relatively high weathering resistant, green poor weathering resistant

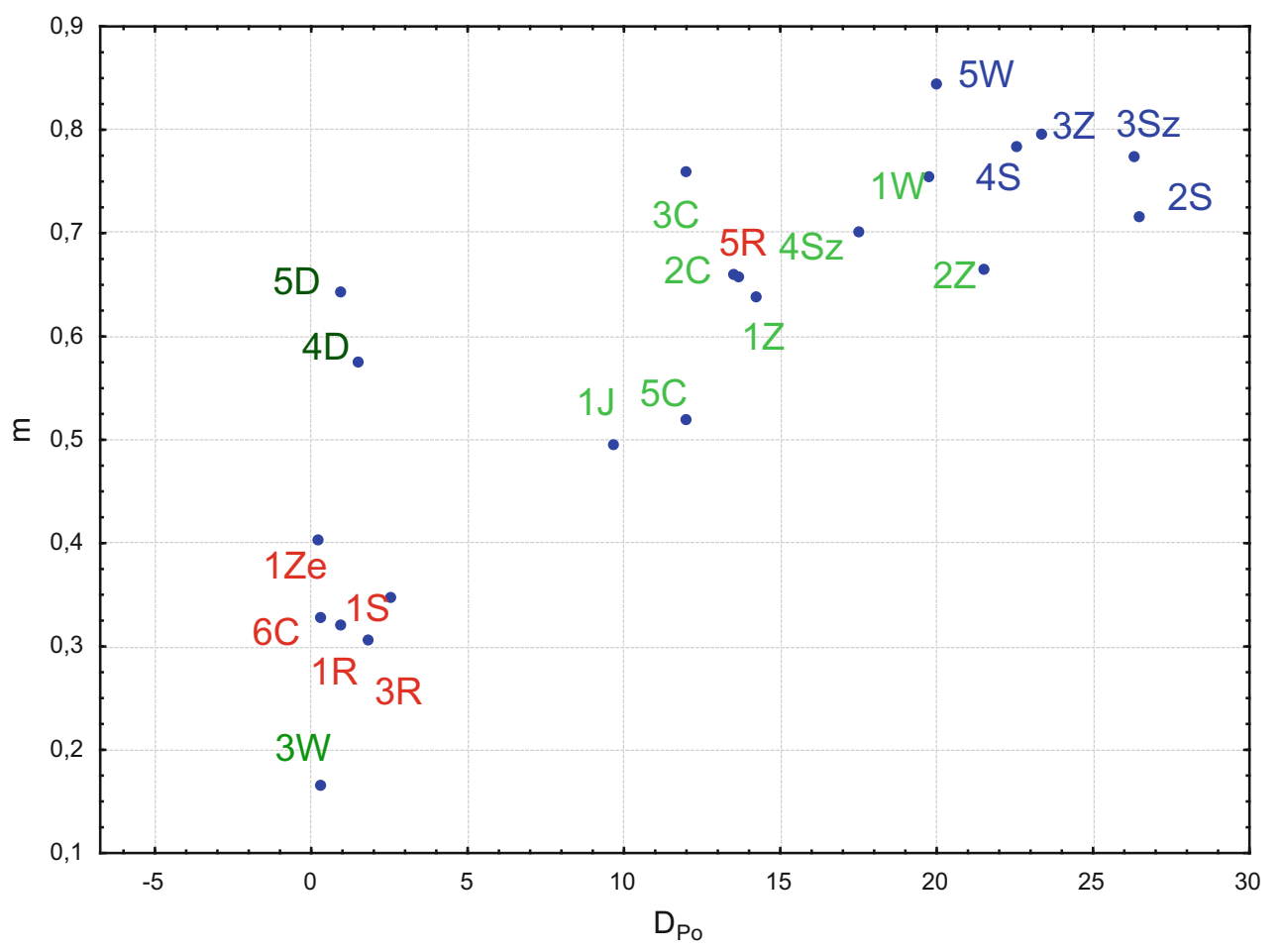

porosity values. The high weathering resistance was determined by cement type (mostly siliceous-argillaceous), and homogeneous (quartz) grain content. The grain contacts were mostly straight, or rarely: concave-convex. The porosimetric cumulative curves were visibly uni-modal, showing the domination of real macropores, mostly in the range from 10 to $100 \mu \mathrm{m}$. Rocks having such porosity characteristics are absorbable, but water is also easily removable. In consequence, the time of water-rock interaction is restricted to rainy periods in natural conditions. Moreover, hysteresis is rather low, which indicates the cylindrical pore shape. This model enables free liquid flow within the rock, reducing the probability of salt crystallization in sandstone pores.

Groups III and IV comprised sandstones of rather low weathering resistance, in a consequence of clay minerals presence in rock cement. Argillaceous-ferruginous or argillaceous-siliceous-ferruginous (base) cement influenced the visible crumbling character of the rocks. The porosimetric cumulative curves showed bimodal shape: dominating pores were in the ranges from 10 to $100 \mu \mathrm{m}$ and from 0.1 to $1 \mu \mathrm{m}$. Similarly as in the case of group II, the macropores made the inflow of water into the pore area of the rock easier, but the presence of submacropores $(0.1-1 \mu \mathrm{m})$ determined the liquid retention in the rock structure, and in consequence, the salt crystallization. Congruently to group II, real macropores enabled the intrusion of water solutions into the rock. However, the existence of submacropores $(0.1-1 \mu \mathrm{m})$, contributed to keeping the water inside, and, in consequence, to the crystallization of salts.

\section{Discussion}

The experimental simulation of stone degradation has had a long tradition. It must be stated, however, that the experimental models do not reflect natural processes sufficiently well, as it is difficult to reflect the real circumstances on the laboratory scale (Ingham 2005).

Natural porosity and especially the pore size distribution are important to evaluate the rock resistance to certain weathering agents, like salt crystallization or thermal shock. In the case of weathering tests on granites (Sousa et al. 2005), low porosity (less than $1.5 \%$ ) does not guarantee any significant weathering changes. Also, the examinations performed on calcarenites (Andriani and Walsh 2002, 2003) showed the essential role of porosity parameters in rock weathering. Grain size seems to exert no direct impact on the permeability, and on the weathering resistance.

Based on the examinations of sandstones, Demarco et al. (2007) stated that the main factors determining the impact of partial water saturation on the rock strength were pore radii distribution and the matrix mineralogy. The conclusions from the undertaken experimental studies seem to be in accordance with this statement.

As a result of rock weathering in the performed laboratory experiment, the values of total porosity usually increased, 
followed by the increase of the specific surface of the pore space and the increase of the mean pore diameter. Many authors have suggested that the increase of the porosity is an indicator of deterioration. Colon et al. (2004) found experimentally the increase in permeability, porosity and surface area as a result of dissolution of sandstones cement. Loss of cement by dissolution reduced the binding forces between grains, which, in consequence, led to the degradation of the pre-existing structure. Grain movement and displacement within the structure, and changes in the distances between grains were considered as a part of the decay processes and indicative of an increase in the weakness of the inter-granular bonds. Snethlage and Wendler (1997) described such process, explaining the deterioration of rocks as expanding spaces in the grain structures, where salt can precipitate and ice crystals can also be formed. Freeze-thaw cycles cause further displacement of grains and contribute to the disaggregation of the grain structure. Thomachot and Jeannette (2002) demonstrated the decrease of fine pores $(<2 \mu \mathrm{m})$ and the increase of large pores in the process of weathering. Such changes may lead to a decrease in capillarity within the material. Changes in the process of deterioration continue to spur further destruction, as frost in bigger pores is more dangerous than in the rock of smaller pores (Fitzner and Kownatzki 1991).

In the conducted experiment, the resulting effect with regard to weathering could only be assessed by further laboratory tests or by strength measurements after the applied laboratory test. Since some of the samples were completely destroyed, the experiment was finished after 100 cycles of chamber rotation. Regarding the samples' dimensions, the strength measurements were not possible to be performed.

This study shows the complexity of the relationship between the pore characteristic and the weathering susceptibility of the sandstone samples. The total porosity is not the only parameter determining the weathering sensitivity. The most important seems to be the pore structure, especially pore radii distribution and hysteresis. The pore size distribution is responsible for the potential of the rock to take in and hold water, and, in consequence to weather.

The pore space is not aligned parallel to the sedimentary bedding. The observations with the use of optical microscopy revealed a rather isotropic nature of the analysed rock fabric. The only element exhibiting oriented sedimentation was ferruginous minerals layering, indicating sedimentary bedding. The preferred alignment caused the anisotropic behaviour of the entire rock, which was clearly visible in the case of samples $1 \mathrm{~W}$ and $5 \mathrm{~W}$. Severe deterioration of sample $1 \mathrm{~W}$ was probably by hydric expansion in the direction perpendicular to the sedimentary layers.

The cycles of wetting and drying, which are similar to natural environmental effects, significantly control the deterioration velocity caused by hydric expansion (Ruedrich et al. 2011; Weiss et al. 2004), especially in the case of sandstones containing clay minerals. Most studies have shown that the rock strength decreases with increasing the moisture content, even for small amounts of water (Demarco et al. 2007; Hawkins and McConnell 1992). Hawkins and McConnell (1992) found that the proportions of quartz and clay minerals, and, to a lesser extent, the rock microfabric, are responsible for strength reduction. Most clay minerals and mica do not show swelling capability, so hydric expansion may be attributed to capillary forces.

In the case of the analysed Polish quader sandstones, the content of clay minerals was rather low. The X-ray analysis and microscopic observations revealed the presence of kaolinite as the dominant clay mineral. Before the experiment, the content of the kaolinite was $1-3 \%$ in the rock samples. The kaolinite crystals were also visible in the sample after CAA experiment (Fig. 9). Kaolinite is not the swelling clay mineral, hence it does not cause severe damage to the rock. When analysing the behaviour of the examined sandstone samples, it must be stated that there is no evident relationship between the sample deterioration and the clay minerals content.

\section{Conclusions}

The characteristic feature of quader sandstones pore area is a trifling share of transitive pores of $10^{-8}$ to $10^{-7} \mathrm{~m}$ diameter (on average $1 \%$ of the pore area). This is the reason for high level of weathering resistance of quader sandstones in comparison with other types of Polish sandstones (Labus 2008). Nevertheless, the quader sandstones are a big group of rocks and their weathering resistance is diversified according to the total porosity, as well as pore size distribution.

Based on the analysis of mercury intrusion porosimetry (MIP) data, four groups of the examined quader sandstones were distinguished. This classification was checked by the experimental modelling of accelerated weathering, conducted in CAA. The results were partially confirmed, hence eventually it was possible to distinguish 3 groups: of high resistance, relatively high resistance and poor weathering resistance. The most important parameter allowing the distinction of the weathering resistance groups is pore size distribution index $m$ inherent with van Genuchten's empirical capillary pressure-saturation function.

Summarizing the performed observations, it could be stated that the physical and mechanical properties of the rocks are essential when assessing their sustainability for use as dimension stone. The dominant mechanism of the examined sandstones deterioration was granular disintegration and weight loss in consequence of samples destruction. 

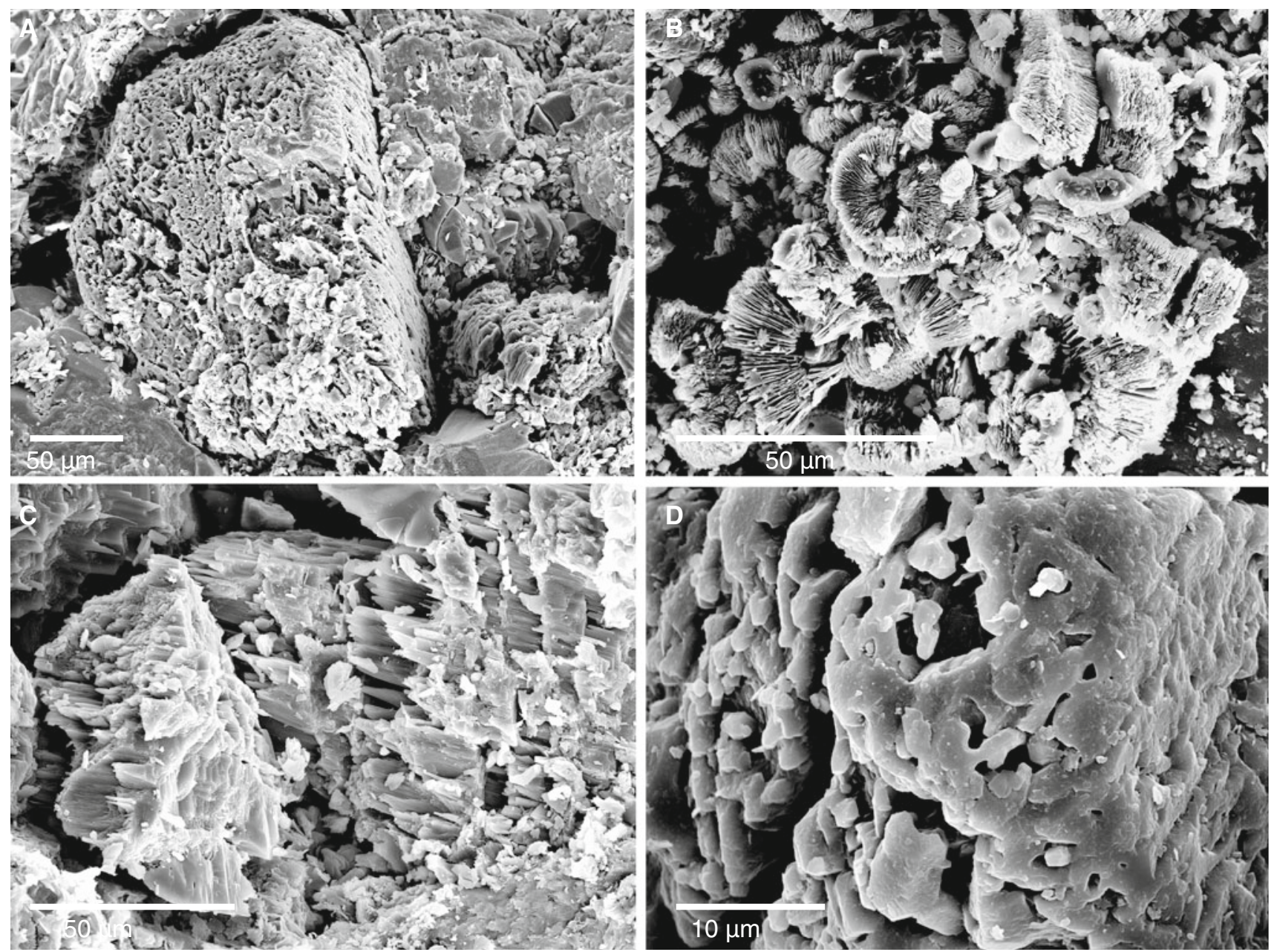

Fig. 9 SEM microphotographs of sandstone samples after the experiment in CAA. a Degradation of K-feldspar grain, covered with kaolinite flakes, sample $2 Z$, magnification $\times 300$, b columnar aggregates of

The main parameters influencing weathering resistance are pore size distribution, texture of the rock and the mineral composition. The effective porosity is a condition of potential for the stone to take in and hold water, and hence to weather. In the samples where the porosity after the experiment increased by $2-4 \%$, the increase of the amount of macropores in the range from 10 to $50 \mu \mathrm{m}$ was visible. The decrease of hysteresis is the evidence of a decrease of ink-bottle pores number.

One of the textural features, influencing the weathering resistance, is the character of grain contacts. The most resistant are sandstones of concave-convex contacts, less resistant are the ones with straight grain contacts. The weakest of the examined sandstones are those with basic or porous cement.

In the case of silica-cemented sandstones, the deciding criterion influencing the weathering resistance is pore size distribution. In the case of sandstones with clay cement, the most important is the mineral composition of the rock. In

kaolinite originating in the weathering process, sample $2 \mathrm{C}$, magnification $\times 1,000$, $\mathbf{c}$ feldspar degradation in sample $4 \mathrm{D}$, magnification $\times 800$, d quartz degradation in sample $1 \mathrm{R}$, magnification $\times 2,200$

the performed weathering experiment, the clay minerals did not play a key role in the weathering phenomenon, as the examined sandstones contained rather small amounts of them. Also, the presence of feldspars in skeletal grains was not the most important factor determining the intensity of weathering phenomenon.

Open Access This article is distributed under the terms of the Creative Commons Attribution License which permits any use, distribution, and reproduction in any medium, provided the original author(s) and the source are credited.

\section{References}

Andriani GF, Walsh N (2002) Physical properties and textural parameters of calcarenitic rocks: qualitative and quantitative evaluations. Eng Geol 67:5-15

Andriani GF, Walsh N (2003) Fabric, porosity and water permeability of calcarenites from Apulia (SE Italy) used as building and ornamental stone. Bull Eng Geol Env 62:77-84 
Bloomfield JP, Gooddy DC, Bright MI, Williams PJ (2001) Porethroat size distributions in Permo-Triassic sandstones from the United Kingdom and some implications for contaminant hydrogeology. Hydrogeol J 9:219-230

Colon CFJ, Oelkers EH, Schott J (2004) Experimental investigation on the effect of dissolution on sandstone permeability, porosity, and reactive surface area. Geochim Cosmochim Acta 68:805-817

Demarco MM, Jahns E, Rudrich J, Oyhantcabal P, Siegesmund S (2007) The impact of partial water saturation on rock strength: an experimental study on sandstone. Z Dtsh Ges Geowiss 158(4):869-882

Ehling A (1999) Die oberkretazischen Bausandsteine Schlesiens (Pertographie, Geochemie, Gesteinstechnische Eigenschaften, Verwitterung und Verwendung sowie Characterisierung ihres Kathodolumineszenz-Verhaltens). Diss Univ Hannover

Evans IS (1970) Salt crystallization and rock weathering: a review. Rev Geomorphol Dyn 19:153-177

Felix C (1983) Sandstone linear swelling due to isothermal water sorption. In: Proceedings of international conference, pp 305-310

Fitzner B (1988) Porosity properties of naturally and artificially weathered sandstones. In: Proceedings of 6th international congress on deterioration and conservation of stone, Torun, pp 136-145

Fitzner B, Basten D (1992) Gesteinporosität - Klassifizierung, me $\beta$ technische Erfassung und Bewertung ihrer Verwitterungsrelevanz, Jahresberichte Steinzerfall - Steinkonservierung, vol 4, Verlag Ernst \& Sohn, Berlin, pp 19-32

Fitzner B, Kownatzki R (1991) Porositätseigenschaften und Verwitterungsverhalten von sedimentären Naturwerksteinen. Bauphysic 13(4):111-119

Ghanbarian-Alavijeh B, Liaghat A, Huang GH, van Genuchten MTh (2010) Estimation of the van Genuchten soil water retention properties from soil textural data. Pedosphere 20(4):456-465

Götze J, Siedel H (2004) Microscopic scale characterization of ancient building sandstones from Saxony (Germany). Mater Charact 53:209-222

Götze J, Siedel H (2007) A complex investigation of building sandstones from Saxony (Germany). Mater Charact 58:1082-1094

Götze J, Siedel H, Magnus M (2007) Provenance determination of building sandstones: a methodology applied to Cretaceous sandstones from Saxony (Germany). Z dt Ges Geowiss 158(4):807-819

Goudie AS, Viles H (1997) Salt weathering hazards. Wiley, New York

Hawkins AB, McConnell BJ (1992) Sensitivity of sandstone strength and deformability to changes in moisture content. Q J Eng Geol 25:115-130

Ingham JP (2005) Predicting the frost resistance of building stone. Q J Eng Geol Hydrogeol 38:387-399
Labus M (2008) Evaluation of weathering-resistance classes in clastic rocks on the example of Polish sandstones. Environ Geol 54(2):283-289

Labus M (2009) Parametry porozymetryczne górnokredowych piaskowców ciosowych jako czynnik warunkujący ich odporność na wietrzenie. Kwart AGH Geol 35(2):263-275

Labus M (2011) Parametry przestrzeni porowej jako determinanty podatności na wietrzenie surowców skalnych - dolnośląskich piaskowców ciosowych, Gliwice

Robertson WD (1985) A three dimensional description of the pore structure in limestone. In: Fifth international congress on deterioration and conservation of stone, Torun

Ruedrich J, Bartelsen T, Dohrmann R, Siegesmund S (2011) Moisture expansion as a deterioration factor for sandstone used in buildings. Environ Earth Sci 63:1545-1564

Siegesmund S, Friedel CH, Vogel J, Mosch S, Naumann D, Peter A, Giesen H (2011) Stability assessment of sandstones from the St. Servatius Church in Quedlinburg (UNESCO's World Heritage Site, Germany). Environ Earth Sci 63:641-659

Skibiński S (1985) Udział soli rozpuszczalnych w wodzie w procesach niszczenia kamiennych obiektów zabytkowych oraz konserwatorskie sposoby ograniczania ich działania. Ochr Zabyt 3-4:244-258

Snethlage R, Wendler E (1997) Moisture cycles and sandstone degradation, saving our architectural heritage: the conservation of historic stone structures. In: Baer NS (ed) Snethlage R, pp 7-24

Sousa LMO, Suarez del Rio LM, Calleja L, Ruiz de Argandona VG, Rodriguez Rey A (2005) Influence of microfractures and porosity on the physico-mechanical properties and weathering of ornamental granites. Eng Geol 77:153-168

Thomachot C, Jeannette D (2002) Evolution of the petrophysical properties of two types of Alsatian sandstone subjected to simulated freeze-thaw conditions. In: Siegesmund S, Weiss T, Vollbrecht A (eds) Natural stone, weathering phenomena, conservation strategies and case studies, vol 205. Geological Society, London, pp 19-32

Turkington AV, Paradise TR (2005) Sandstone weathering: a century of research and innovation. Geomorphology 67:229-253

van Genuchten MTh (1980) A closed-form equation for predicting the hydraulic conductivity of unsaturated soils. Soil Sci Am J 44:892-898

Weiss T, Siegesmund S, Kircher D, Sippel J (2004) Insolation weathering and hygric dilatation: two competitive factors in stone degradation. Env Geol 46:402-413

Wells T, Binning P, Willgoose G, Hancock G (2006) Laboratory simulation of the salt weathering of schist: 1 . Weathering of schist blocks in a seasonally wet tropical environment. Earth Surf Proc Landf 31:339-354

Winkler EM (1975) Stone: properties, durability in man's environment. Springer, New York 